ISSN : 2615-1995, E-ISSN : 2615-0654

J. Madani., Vol. 1, No. 2, September 2018 (473-488)

(c)2018 Lembaga Kajian Demokrasi

MADANI

dan Pemberdayaan Masyarakat (LKD-PM)

\title{
KONSEP SABAR DALAM AL-QUR'AN
}

\author{
Sopyan Hadi \\ Fakultas Ekonomi, Universitas Pamulang \\ dosen00292@unpam.ac.id
}

\begin{abstract}
Abstrak
Penelitian ini berjudul: "Hakikat Sabar dalam Al-Quran", mencoba mengangkat studi komparatif penafsiran Prof. HAMKA di dalam Tafsir Al-Azhar dan Prof. M. Quraish Shihab di dalam Tafsir AlMishbah. Penulis memilih topik tersebut didorong oleh rasa ingin tahu tentang kurang tepatnya pemahaman masyarakat muslim Indonesia tentang sabar yang hakiki. Dalam banyak kesempatan, penulis sering menemukan pengertian sabar yang diidentikkan dengan "bertahan hidup dalam kemiskinan dan kemalangan", atau "terpaksa" menerima musibah". Dalam konteks ini, sabar dimasukkan ke dalam wilayah yang "pasif" atau "terpaksa". Akan tetapi, ketika penulis mencermati beberapa ayat tentang sabar, antara lain perintah Allah Swt untuk meminta pertolongan dengan sabar dan shalat (QS al-Baqarah: 45), penulis berpendapat bahwa ayat tersebut dan ayat-ayat sabar yang lain, semestinya dipahami dengan kerangka "sabar yang aktif dan produktif". Hasil penelitian tesis ini menunjukkan bahwa sabar ialah suatu karakter atau perangai budi yang sangat utama dimiliki oleh setiap muslim untuk mempertahankan harkat dan martabatnya sebagai muslim yang unggul. Sabar semestinya dimiliki oleh setiap muslim ketika mendapatkan nikmat maupun ujian, dalam keadaan lapang maupun sempit, senang atau susah. Baik Prof. Hamka dan Prof. Dr. M. Quraish Shihab memandang hakikat sabar adalah kemampuan seseorang dalam mengendalikan emosi agar mampu bertahan dalam kebaikan dan keburukan. Sabar menurut HAMKA adalah suatu sikap dari jiwa yang besar dan terlatih, yang akan diperoleh dengan jalan mengendalikan diri, tabah dalam menghadapi segala ujian, dengan disertai bersyukur kepada Allah dan memegang teguh ketakwaan, sedangkan menurut M. Quraish Shihab adalah keberhasilan menahan gejolak hati demi maencapai sesuatu yang baik dengan jalan mensucikan Tuhan.
\end{abstract}

Kata Kunci : Konsep Al-Quran, Buya Hamka, M. Quraish Shihab

\section{PENDAHULUAN}

\section{Latar Belakang}

Islam merupakan agama paripurna yang memposisikan akhlak mulia (budi pekerti) sebagai bagian integral dalam sistem ajaran Islam yang mencakup aqidah (doktrin atau keyakinan agama) dan syariah (aturan Allah untuk manusia). Prof. Mahmud Syaltut dalam bukunya, Al-Islâm 'Aqîdah wa Syarî́ah, memandang bahwa akhlak atau budi pekerti merupakan cabang yang paling utama di dalam sistem aqidah dan syariat Islam.
Salah satu akhlak mulia yang ditekankan di dalam Islam adalah sabar. Akhlak ini sangat dibutuhkan oleh setiap muslim dalam menjalani kehidupannya yang tidak luput dari berbagai ujian dan cobaan, serta cita-cita dan harapan untuk menuai kesuksesan.

Melihat kedudukannya yang penting di dalam Islam, para ulama sejak dahulu telah mencurahkan perhatiannya yang besar untuk mengkaji hakikat sabar di dalam Al-Qur'an.

Sehubungan dengan banyaknya redaksi ayat Al-Qur'an yang berbicara tentang kesabaran, 
Muhammad Rasyid Ridha mengatakan: "Tidak ada akhlak utama lain di dalam Al-Qur'an yang disebutkan dengan jumlah sebanyak sabar. Ini mengandung pemahaman betapa pentingnya persoalan ini."

Kekeliruan sebagian masyarakat dalam memahami dan mempraktikkan kesabaran, boleh jadi disebabkan oleh redaksi-redaksi yang merujuk kata sabar di dalam Al-Quran secara umum. Ayat-ayat Al-Qur'an yang membicarakan akhlak ini pada umumnya berupa perintah, larangan, dan keutamaan yang akan dicapai oleh orang yang sabar. Sedangkan, teksteks Al-Qur'an tidak memberikan petunjuk yang jelas dan memadai mengenai pengertian sabar dan cara mempraktikkannya di dalam kehidupan sehari-hari-hari.

Permasalahan diatas membuat penulis tertarik untuk mengangkat tema tesis ini dengan judul: "Hakikat Sabar dalam Al-Qur'an: Studi Komparatif Penafsiran HAMKA dan M. Qurasih Shihab". Dengan demikian, tulisan ini berusaha membandingkan pandangan tentang hakikat kesabaran dari dua tokoh tafsir Indonesia dalam karya tafsir mereka.

Penyusunan tesis ini merupakan upaya untuk menemukan jawaban yang berdasarkan Al-Qur'an tentang hakikat kesabaran. Sebab, masyarakat Islam pada umumnya belum mengetahui secara utuh hakikat kesabaran yang Qur'ani.

\section{Pembatasan dan Perumusan Masalah}

Penulis membatasi pembahasan tesis ini dalam dua hal, yaitu:

1. Masalah utama yang dibahas dalam tesis ini adalah tentang hakikat sabar di dalam Al-Quran.

2. Hakikat sabar yang dikaji dalam tesis ini adalah hakikat sabar berdasarkan AlQuran yang dikemukakan oleh HAMKA dan M. Quraish Shihab.

Adapun masalah dalam tesis ini penulis rumuskan ke dalam pertanyaan-pertanyaan berikut:

1. Apa hakikat sabar dalam Al-Quran menurut HAMKA dan M. Quraish Shihab?

2. Bagaimana pandangan HAMKA dan M. Quraish Shihab dalam tafsirnya tentang keutamaan atau buah-buah sabar di dunia dan akhirat?
3. Bagaimana sabar yang harus diterapkan dalam kehidupan umat Islam menurut dua mufassir tersebut?

4. Bagaimana pendapat kedua mufassir tentang akibat perilaku tidak sabar.

Dari rumusan masalah tersebut, penulis juga membatasi sumber utama dalam penulisan ini, yaitu Tafsir al-Azhar karya Prof. Dr. H. Abdul Malik Abdul Karim Amrullah pengarang Tafsir al-Azhar dan Tafsir al-Misbah karya Prof. Dr. H. Muhammad Qurasih Shihab.

\section{Tujuan dan Kegunaan Penelitian}

Kajiian tentang hakikat sabar dalam AlQuran yang mengkomparasikan pandangan dua tokoh tafsir Indonesia ini bertujuan sebagai berikut:

1. Mengetahui hakikat sabar dan keutamaannya dalam Al-Quran serta akibat perilaku tidak sabar menurut penafsiran Prof. HAMKA dalam Tafsir al-Azhar dan Prof. Dr. H. Muhammad Qurasih Shihab dalam Tafsir al-Misbah.

2. Melihat persamaan dan perbedaan penafsiran kedua mufassir tersebut terhadap ayat-ayat sabar dalam Al-Quran dengan memperhatikan kerangka metodologis yang mereka gunakan di dalam penafsirannya.

3. Mengimplementasikan konsep sabar dalam Al-Qur'an sebagai perilaku atau sikap yang utama bagi kehidupan muslimin.

Adapun kegunaan penelitian ini adalah sebagai berikut:

1. Menambah kaya tulis yang membahas tentang hakikat sabar dalam Al-Quran menurut pandangan dua pakar tafsir Indonesia, yaitu Prof. HAMKA dan Prof. Dr. M. Qurasih Shihab.

2. Memberikan kontribusi terhadap terciptanya perilaku sabar dalam kehidupan masyarakat muslim Indonesia.

3. Memberikan dorongan kepada pembaca karya tulis ini untuk menulis tulisan serupa dari perpektif ulama atau mufassir yang berbeda.

\section{TINJAUAN PUSTAKA}

\section{A. Definisi Sabar}

1. Makna Etimologi

Sabar adalah kata serapan dari bahasa 
Arab, yaitu sha/b/r, terdiri atas huruf shâd, bâ', $r a \hat{}$. Kata shabr merupakan bentuk mashdar (pembendaan) dari kata sha/ba/ra. Dari segi leksikal, kata shabara memiliki beragam arti. Jika diikuti partikel 'alâ bermakna sabar atau tabah hati, diikuti partikel 'an berarti amsaka (menahan atau mencegah), diikuti partikel hu berarti akraha wa alzama (memaksa dan mewajibkan), dan bila diikuti partikel $b i$ berarti kafala (menanggung). Sebagai contoh “

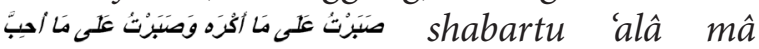
akrah wa shabartu 'an mâ uhibb" (saya besabar atau tabah terhadap apa yang saya benci dan menahan atau mencegah diri dari apa yang saya sukai).

Menurut Luwis Ma'luf, kata shabara jika diikuti partikel 'ala bermakna luas: jaru'a (berani), syaju'a (kuat mentalnya) dan tajallâ (menampakkan diri). Ibn Manzhur menjelaskan, makna asal dari shabr adalah menahan, seperti mengurung binatang, menahan diri, dan mengendalikan diri. Sehubungan dengan ini, maka puasa disebut juga sabar (menahan makan minum) dan bulan puasa dinamakan bulan sabar (syahr al-shabr). Sebab, orang yang puasa menahan diri dari makan, minum, dan godaan nafsu selama berpuasa sebulan penuh.

Sementara itu, Ibn Faris menyebutkan dua arti shabr yaitu a'la al-sya'i (puncak sesuatu) dan jins min al-hijârah (sejenis batu). Dua arti ini berkaitan dengan arti kata shabara sebelumnya. Sebab, kedudukan sabar sangat mulia dan orang yang sabar memiliki kekokohan jiwa laksana batu. Kata al-shabr juga berarti konsisten (alistiqâmah wa al-mudâwamah) dan menunggu (al-intizhâr). Kata shabara melahirkan kata lain shâbara, ashbara dan ishthabara. Kata shâbara menunjukan arti peningkatan intensitas.

\section{Makna Terminologi}

Secara terminologis, sabar didefinisikan secara beragam oleh para ulama. Beragamnya definisi tentang sabar diakibatkan oleh perbedaan cara pandang mereka dalam memahami sabar di dalam Al-Qur'an, di samping pula karena latar belakang keilmuan ulama itu sendiri. Namun, umumnya ulama yang membicarakan sabar adalah mereka yang mempunyai latar belakang tasawuf. Hal ini karena sabar termasuk kajian utama di dalam tasawuf.

Di antara definisi sabar yang populer ialah sebagai berikut:
1). Menurut al-Muhâshibî (w. 243 H/857 M), sabar ialah "mengurung diri di tempat penghambaan (ubûdiyyah) dan membuang rasa gelisah. Orang yang telah mampu membuang rasa gelisah, berarti telah berada di maqam penghambaan (ubûdiyyah)".

2). Menurut Dzû al-Nûn (w. 246 H/861 M), sabar ialah "menghindarkan diri dari pertentangan (mukhâlafah), tenang ketika ditimpa musibah, dan menampakan diri berkecukupan ketika mengalami kefakiran". Sabar dalam Al-Qur'an mengandung unsur perbuatan. Artinya, sabar adalah suatu sikap yang mendorong kepada perbuatan dan pelaksanaan perbuatan dengan baik. Bagi kaum muslim, hal itu merupakan pengertian yang tidak asing, bahkan menjadi spirit dan motivasi dalam beramal. Hal ini bisa diukur dengan rentang waktu yang dipergunakan untuk ketahanan diri dan ketabahan dalam menghadapi berbagi kesulitan dan musibah.

Dari uraian di atas dapat kita simpulkan bahwa sabar merupakan suatu sikap yang amat agung dalam pandangan Islam.

\section{B. Ayat-Ayat Sabar dalam Al-Qur'an}

Al-Qur'an sebagai sumber segala ilmu pengetahuan telah menyinggung kata sabar di banyak surat dan ayat. Dalam hitungan para ulama, kata sabar di dalam Al-Qur'an disebutkan di dalam 70 ayat lebih atau 100 kata lebih. Para ulama berbeda pendapat mengenai jumlah ayat sabar atau kata sabar di dalam Al-Qur'an. Jumlah ayat Al-Qur'an yang mengandung kata sabar adalah sebagaimana pendapat berikut:

1. Abû Thâlib al-Makki, menyebutkan kata sabar dalam al-Qur'an lebih dari 90 kali.

2. Abû Hâmid al-Ghazâlî, menyebutkan kata sabar dalam al-Qur'an lebih dari 70 tempat. Adanya perbedaan yang terjadi di kalangan ulama dalam menentukan jumlah kata shabr yang tersurat di dalam Al-Qur'an, menurut alQardhawi, bukan berarti terdapat kontradiksi di dalam Al-Qur'an itu sendiri. Perbedaan tersebut terjadi karena dalam beberapa ayat terdapat dua kata shabr atau lebih yang oleh sebagian ulama dihitung satu dan sebagian lain menghitungnya dua atau lebih. 


\section{Biografi Hamka dan M. Quraish Shihab Biografi Hamka}

1. Latar Belakang Keluarga

HAMKA (selanjutnya ditulis Hamka) adalah akronim atau potongan dari nama panjang Haji Abdul Malik Karim Amrullah. Ia dilahirkan di Sungai Batang, Maninjau, Sumatera Barat, pada 17 Februari 1908 bertepatan dengan 14 Muharram 1326 Hijriyah. Ayahnya, Syekh Abdul Karim bin Amrullah, yang dikenal dengan sebutan Haji Rasul, adalah seorang ulama pelopor gerakan pembaruan (tajdid) yang terkenal di Minangkabau dan Sumatra.

Pendekatan-pendekatan yang dilakukan ketiga ulama tersebut - yang kemudian dikenal dengan sebutan tiga serangkai - mendapat reaksi yang cukup keras dari umat Islam di Sumatra Barat, terutama dari kalangan tua. Merekapun dicaci dan dimaki serta dituduh keluar dari madzhab ahlus-sunah wal jamaah, mu'tazilah, wahabi dan khawarij dan sebagainya. Bahkan, tuduhan sesat pun pernah dialami orang tua Hamka bersama tiga serangkainya.

\section{Riwayat Pendidikan}

Hamka mendapat pendidikan formalnya yang pertama di Sekolah Dasar Maninjau, yang dikenal dengan sebutan sekolah desa. Kemudian pada 1916, ketika Zaibuddin Labai el-Yunusi mendirikan Sekolah Diniyah petang hari di Pasar Usang, Hamka dimasukkan ke sekolah itu. Dengan demikian, pagi hari Hamka sekolah di sekolah desa, sore harinya ia sekolah di sekolah agama - ketika itu sekolah agama tidak begitu dikenal di kalangan murid-murid, yang dikenal adalah sekolah Arab - dan ketika malam hari Hamka mengaji Al-Quran di Surau bersama dengan teman-temannya.

Setelah ayahnya mendirikan Sumatra Thawalib di Padang Panjang, Hamka berhenti dari sekolah desa dan kemudian dimasukkan ke Sumatra Thawalib, ketika itu Hamka berumur 10 tahun. Sumatra Thawalib dulunya adalah surau Jembatan Besi, tempat kakeknya Syekh Abdul Karim memberikan pelajaran agama, kemudian surau, yang merupakan sistem pendidikan klasik diubah menjadi sistem pendidikan semi modern (madrasah). Di Sumatra Thawalib inilah Hamka mempelajari buku-buku agama dan mendalami bahasa Arab.

Hamka adalah seorang otodidiak dalam berbagai bidang ilmu pengetahuan seperti filsafat, sastra, sejarah, sosiologi dan politik, baik Islam maupun Barat. Dengan kemahiran bahasa Arabnya yang tinggi, ia dapat menyelidiki karya ulama dan pujangga besar di Timur Tengah seperti Zaki Mubarak, Jurji Zaidan, Abbas al-Aqqad, Mustafa al-Manfaluti dan Hussain Haikal. Melalui bahasa Arab juga, beliau meneliti karya sarjana Perancis, Inggris dan Jerman seperti Albert Camus, William James, Sigmund Freud, Arnold Toynbee, Jean Paul Sartre, Karl Marx dan Pierre Loti. Hamka juga rajin membaca dan bertukartukar pikiran dengan tokoh-tokoh terkenal Jakarta seperti HOS Tjokroaminoto, Raden Mas Surjoparonoto, Haji Fachrudin, Ar Sutan Mansur dan Ki Bagus Hadikusumo sambil mengasah bakatnya menjadi seorang ahli pidato yang handal.

\section{Karya-Karya Ilmiah}

Menurut penuturan pengurus Yayasan AlAzhar, Hamka telah menghasilkan lebih dari 115 karya di bidang sastra, sejarah, tasawuf dan agama. Di antara karya-karya beliau antara lain:

1) Antara fakta dan Khayal "Tuanku Rao"

2) Ayahku (Biografi Dr. H. A. Karim Amrullah)

3) Beberapa Tantangan Terhadap Umat Islam di Masa Kini

4) Bohong di Dunia

5) Dari Lembah Cita-Cita

6) Di Bawah Lindungan Ka'bah

7) Di Dalam Lembah Kehidupan

8) Islam Adat Minangkabau

9) Kenang-Kenangan Hidup

10) Kisah Nabi-Nabi

11) Lembaga Hikmat

12) Merantau ke Deli

13) Pandangan Hidup Muslim

14) Pelajaran Agama Islam

15) Perkembangan Kebatinan di Indonesia

16) Pribadi

17) Renungan Tasawuf

18) Said Jamaluddin al-Afghani, Pelopor Kebagkitan Muslimin

19) Sejarah Islam di Sumatra

20) Sejarah Umat Islam

21) Tafsir Al-Azhar

22) Tanya Jawab

23) Tasawuf Modern

24) Tenggelamnya Kapal Van der Wijk

25) 1001 Soal-Soal Hidup 


\section{B. Mengenal Tafsir Al-Azhar}

1. Riwayat Penulisan

Tafsir Al-Azhar berasal dari ceramah kuliah subuh yang diberikan oleh Hamka di Masjid Agung Al-Azhar Jakarta sejak tahun 1959-an. Atas usul Haji Yusuf Ahmad, pelajaran tafsir yang diceramahkannya di masjid Al-Azhar itu, kemudian dimuat di majalah Gema Islam. Pasa waktu itu Hamka langsung memberikan nama pada tafsirnya Tafsir Al-Azhar, karena tafsir tersebut muncul dari masjid Al-Azhar.

Pada Hari Senin tanggal 12 Ramadhan 1383 atau bertepatan dengan 27 Januari 1964, tanpa diduga sebelumnya, Hamka ditangkap oleh sesaat setelah ia memberikan pengajian dihadapan kaum Ibu di Masjid Al-Azhar. Seperti diceritakan dalam mukaddimah Tafsir Al-Azhar, ia dituduh hendak mengadakan kudeta kepada pemerintah. Lebih dari itu, Hamka dituduh telah menghasut mahasisiwa agar meneruskan pemberontakan Kartosuwiryo, Daud Beureuh, M. Natsir dan Safruddin Prawiranegara.

Sebagai tahanan politik, Hamka ditempatkan di beberapa rumah peristirahatan di kawasan puncak, yakni Bungalow Herlina, Harjuna, Bungalow Brimob, Mega Mendung, dan kamar tahanan polisi Cimacan. Di rumah tahanan inilah Hamka menyempatkan diri menulis Tafsir Al-Azhar. Namun, disebabkan kesehatannya yang menurun, Hamka kemudian dipindahkan ke rumah sakit Persahabatan, Rawamangun Jakarta. Dan selama dalam perawatan di rumah sakit, Hamka meneruskan penulisan Tafsir Al-Azhar.

Setelah orde lama tumbang dan orde baru muncul dibawah kepemimpinan Soeharto, lantas kekuatan PKI pun ditumpas. Pada tanggal 21 Januari 1966, Hamka dibebaskan dari tahanan setelah sebelumnya mendekam selama lebih kurang dua tahun. Kesempatan ini dipergunakan Hamka untuk memperbaiki dan menyempurnakan Tafsir Al-Azhar yang ditulisnya di beberapa rumah tahanan sebelumnya.

Penerbitan Tafsir Al-Azhar edisi pertama juz I diterbitkan oleh Pembimbing Masa Jakarta, edisi pertama merampungkan penerbitan dari juz I sampai juz III. Setelah terhentinya penerbit Pembimbing Masa, kemudian diteruskan oleh Yayasan Nurul Islam yang juga penerbit majalah Panji Masyarakat yang dipimpin Hamka sendiri. Penerbitan itu pun sampai jilid atau juz XV. Disamping Pustaka Panjimas yang kebagian menerbitkan 15 jilid, dari juz XVI sampai Juz XXX, oleh pengarangnya diserahkan pada Pustaka Islam Surabaya. Dan pada tanggal 17 Februari 1981 bertepatan dengan hari lahir Hamka, penerbitan Tafsir Al-Azhar telah lengkap.

\section{Corak dan Metodologi}

Dalam studi ilmu tafsir dikenal berbagai corak ragam penafsiran. Corak-corak penafsiran yang dikenal selama ini antara lain:

a. Corak Sastra Kebahasaan

b. Corak Filsafat dan Teologi

c. Corak Ilmiah

d. Corak Hukum/Fiqh

e. Corak Tasawuf

f. Corak Sastra Budaya Kemasyarakatan. yaitu corak tafsir yang menjelaskan petunjukpetunjukayat-ayat Al-Qur'an yangberkaitan langsung dengan kehidupan masyarakat serta usaha-usaha untuk menangulangi penyakit-penyakit/problem-problem masyarakat mereka berdasarkan ayat-ayat dengan mengemukakan petunjuk-petunjuk tersebut dalam bahasa yang mudah dimengerti tapi indah terdengar.

Corak tafsir ini bermula dari Syekh Muhammad Abduh (1849-1905). Dan ini pula yang ditempuh oleh Hamka dalam Tafsir AlAzhar. Boleh jadi, ini dikarenakan Hamka menyukai tokoh-tokoh modernis semisal beliau, Muhammad Rashid Ridha, juga Sayid Qutub. Bahkan ia mengatakan bahwa tafsir Sayid Qutub sangat banyak memperngaruhi Hamka dalam menulis Tafsir Al-Azhar.

Lebih lanjut Hamka memandang bahwa Indonesia yang penduduk muslimnya lebih banyak dari penduduk lainnya, sedang haus akan bimbingan agama dan haus akan rahasiarahasia Al-Quran. Karenanya, permasalahanpermasalahan yang tidak penting seperti pertikaian-pertikain madzhab tidak dibawanya dalam tafsirnya, dan ia tidak ingin ta'ashub kepada suatu paham melainkan ia mencoba mendekati maksud ayat dengan menguraikan makna dari lafadz bahasa Arab ke dalam bahasa Indonesia dan memberi kesempatan orang untuk berpikir.

Sedangkan metodologi penafsiran yang ditempuh Hamka dalam Tafsir Al-Azhar adalah condong kepada metode tahlîlî atau 
tajzi'̂, yaitu sebuah metodologi tafsir, yang mufassirnya berusaha menjelaskan kandungan ayat-ayat Al-Quran dari berbagai segi dengan memperhatikan runtutan ayat-ayat Al-Quran sebagaimana tercantum di dalam mushaf AlQuran.

\section{A. Biografi M. Quraish Shihab}

1. Latar Belakang Keluarga

Muhammad Quraish Shihab lahir di Rappang, Sulawesi Selatan pada tanggal 16 Februari 1944 M. Ayahnya, Abdurrahman Shihab (1905-1986) adalah guru besar bidang tafsir Al-Qur'an. Di samping berwiraswasta, sejak muda Abdurrahman Shihab berdakwah dan mengajar. Setiap pagi dan petang, ia selalu berusaha menyisakan waktunya untuk membaca Al-Quran dan kitab-kitab tafsir.

Dalam penuturan Quraish Shihab, ia pertama belajar bahasa Al-Quran langsung dari ayah kandungnya sendiri, yang secara rutin dilaksanakan setiap habis maghrib. "Ayah selalu mengajak saya dan saudara-saudara yang lain untuk bercengkrama bersama dan sesekali memberikan petuah-petuah keagamaanya", kata Quraish Shihab.

Banyak dari petuah-petuah ayahnya, kemudian hari diketahui oleh Quraish sebagai ayat Al-Quran, atau hadits Nabi, atsar sahabat atau petuah dari pakar-pakar Al-Quran. Di antara petuah-petuah tersebut antara lain:

"Aku palingkan (tidak memberikan) ayatayat-Ku kepada mereka yang bersikap angkuh di permukaaan bumi..." (QS. Al-A'raf [7]: 146)

"Al_Quran adalah jamuan Tuhan..." demikian bunyi sebuah hadits. Rugilah yang tidak menghadiri jamuan-Nya. Dan lebih rugi lagi yang hadir tetapi tidak menyantapnya.

"Biarkanlah Al-Quran berbicara (Istantiq Al-Quran)..." kata 'Alî ibn Abî Thâlib.

"Bacalah Al-Quran seakan-akan ia diturunkan kepadamu” kata Muhammad Iqbal.

"Rasakan keagungan Al-Quran sebelum kau menyentuhnya dengan nalarmu" kata Syaikh Muhammad 'Abduh.

"Untuk mengantarkanmu mengetahui rahasia ayat-ayat Al-Quran, tidaklah cukup engkau membacanya empat kali dalam sehari..." kata al-Maudûdî

Itulah sebagian diantara petuah-petuah ayah Quraish yang masih terngiang-ngiang di telinganya. Dari petuah-petuah yang diberikan ayahnya itulah, menurutnya, benih-benih kecintaannya kepada studi Al-Quran mulai tersemai dan tumbuh di dalam jiwanya.

Disamping dukungan sang ayah, dukungan dan pengaruh sang ibu, juga dianggap Quraish Shihab sangat berpengaruh dalam keberhasilannya saat ini. Seperti diceritakannya, sang ibu, selain senantiasa mendorong anak-anaknya untuk belajar, ia juga seorang yang sangat ketat dalam urusan agama. Ketat yang dimaksudkan di sini adalah ia selalu mengukur segala sesuatu dalam urusan agama dari sudut Al-Quran dan Al-Hadits.

Kalau melihat latar belakang seperti di atas, tak mengherankan jika minat Quraish Shihab terhadap studi Al-Quran sangatlah besar. Hal ini bisa terlihat dari ketekunannya dalam mempelajari studi-studi Al-Quran bahkan hingga ke perguruan tinggi.

\section{Riwayat Pendidikan}

Setelah menyelesaikan pendidikan dasarnya di Ujung Pandang, Quraish melanjutkan pendidikan menengahnya di Malang, Jawa Timur, sambil "nyantri" di Pondok Pesantren DarulHadits Al-Faqihiyyah.

Selanjutnya, pada 1958, Quraish berangkat ke Kairo Mesir atas bantuan beasiswa dari Pemerintah Daerah Sulawesi. Namun, Quraish hanya bisa diterima di kelas II Tsanawiyyah Al-Azhar. Kendati begitu, demi mengejar 'ambisinya' untuk belajar tafsir Al-Quran, ia tak keberatan mengulang satu tahun untuk mendapat kesempatan melanjutkan studi tafsir, padahal dengan nilai yang dicapainya, jurusanjurusan yang lain pada fakultas yang berbeda sudah membuka pintu lebar-lebar untuknya. Bahkan ia juga diterima di Univesity of Cairo dan Dar al-Ulum Mesir.

Pada 1967, Quraish Shihab berhasil meraih gelar Lc (S-1) pada Fakultas ushuluddin Jurusan Tafsir dan Hadits Universitas Al-Azhar. Kemudian ia melanjutkan pendidikannya di Fakultas yang sama, dan pada (1969) ia meraih gelar MA (Master of Art) untuk spesialisasi bidang tafsir Al-Quran dengan tesis berjudul "al-I'jaz al-Tasyri î li al-Qur'ân al-Karim."

Setelah menamatkan pendidikan S-2 nya, Quraisy memilih istirahat dan kembali ke Ujung Pandang. Sebelas tahun kemudian, tepatnya pada 1980, Quraish Shihab kembali lagi ke Kairo melanjutkan studinya S-3 nya 
dalam bidang tafsir di almamater yang sama, yaitu Universitas Al-Azhar. Dan ia pun berhasil meraih gelar doktor dalam bidang ilmu-ilmu Al-Quran pada tahun 1982, dengan disertasi berjudul "Nazhm al-durar li al-biqa' $\hat{\imath}$, tahqiq wa dirasah" dengan yudisium Summa Cum Laude (mumtaz ma'a martabat al-syaraf al-ula).

Dengan predikat yang tinggi dan memuaskan tersebut, Quraisy Shihab dinobatkan sebagai orang pertama Asia Tenggara yang meraih gelar doktor dalam bidang Ilmu Tafsir, dan sekaligus - menurut pandangan para sarjana muslim Indonesia - menjadikan ia sebagai master tafsir Indonesia abad modern.

\section{B. Mengenal Tafsir Al-Misbah}

1. Riwayat Penulisan

Diantara yang melatarbelakangi penulisan tafsir Al-Misbah adalah pengalaman Qurash Shihab selama belasan tahun mengajar di perguruan tinggi. Dalam satu semester misalnya, Qurash Shihab bersama mahasiswanya hanya mampu menyelesaikan pembahasan belasan ayat. Karena di dalam pembahasan terjadi banyak pengulangan dan tidak terhidangnya makna kosakata sebagaimana yang digunakan Al-Quran atau kaidah-kaidah tafsir yang dapat ditarik dari kitab suci. Hal ini menjadikan mahasiswa tidak dapat memahami pesan-pesan Al-Qur'an dalam waktu yang relatif singkat.

Berangkat dari pengalaman tersebut, maka pada tahun 1997, penerbit Pustaka Hidayah menerbitkan karya Qurash Shihab yang berjudul "Tafsir Al-Quran al-Karim". Ada 24 surat yang dihidangkan dalam buku tersebut. Uraian-uraian banyak merujuk kepada AlQuran dan al-Sunah dengan menggunakan metode tahlîlî, takni menafsirkan ayat demi ayat sesuai dengan susunannya dalam setiap surah. Penekannnya dalam uraian-uraian tafsir tersebut adalah pada pengertian kosakata dan ungkapan-ungkapan Al-Quran dengan merujuk kepada pandangan pakar bahasa, kemudian memperhatikan bagaimana kosakata atau ungkapan itu digunakan oleh Al-Quran.

Dalam buku Tafsir Al-Quran al-Karim tersebut, uraian-uraian surah yang diuraikan Qurash Shihab didasarkan pada urutan masa turun, dimulai dengan Al-Fatihah, sebagai induk Al-Quran, disusul dengan surah yang memuat wahyu pertama (iqra') yaitu surat Al'Alaq, selanjutnya Al-Muddatsir, Al-Muzammil, dan seterusnya hingga Al-Tahriq.

Menghidangkan tafsir Al-Quran berdasarkan urutan-urutan turunnya diharapkan oleh Qurash Shihab dapat mengantarkan pembaca mengetahui runtutan petunjuk ilahi yang dianugrahi kepada Nabi Muhammad saw. dan umatnya. Di sisi lain - menurut Qurash Shihab - menguraikan tafsir Al-Quran berdasarkan urutan surah-surah dalam mushhaf seringkali menimbulkan banyak pengulangan jika kandungan kosakata atau pesan ayat dan suratnya mirip atau bahkan sama dengan ayat atau surat yang sudah ditafsirkan sebelumnya. Ini diperlukan waktu yang cukup banyak untuk mempelajai kitab suci. Oleh karenanya, dalam tafsir tersebut, Qurash Shihab memaparkan makna kosakata sebanyak mungkin dan kaidahkaidah tafsir yang menjelaskan makna ayat dan sekaligus dapat digunakan untuk memahami ayat-ayat lain.

Akhirnya Qurash Shihab menyadari bahwa apa yang dihidangkan dalam buku tafsirnya tersebut kurang menarik minat kebanyakan orang, bahkan sebagian pembaca menilainya terlalu bertele-tele dalam uraiannya tentang pengertian kosakata atau kaidah yang disajikan. Cara penghidangan seperti dalam buku tersebut boleh jadi memang cocok untuk kalangan yang sudah belajar mata kuliah tafsir atau yang memang mengambil spesialisasi dalam bidang tafsir, bukan untuk konsumsi umum. Setelah menyadari hal tersebut, akhirnya Qurash Shihab tidak lagi melanjutkan upaya-upaya tersebut.

\section{Corak dan Metodologi}

Jika ditilik dari corak-corak penafsiran yang ada, corak penafsiran yang dilakukan oleh Quraish Shihab dalam Tafsir Al-Misbah tidaklah berbeda dengan corak yang ditempuh oleh Hamka dalam Tafsir Al-Azhar, yaitu sama-sama mengambil corak sastrabudaya kemasyarakatan, yang dalam istilah Islah Gusmian disebut juga nuansa sosial kemasyarakatan. Hal ini karena penulisannya dilatarbelakangi oleh kebutuhan masyarakat akan Al-Quran dan penafsiran atasnya. Disamping juga karena banyaknya permasalahan yang dihadapi masyarakat, yang menuntut adanya pemahaman mengenai $\mathrm{Al}$ Quran.

Sedangkan metodologi yang digunakan 
adalah condong pada metodologi tahlîlî, yaitu sebuah metodologi tafsir yang berusaha menjelaskan kandungan ayat-ayat Al-Quran dari berbagai seginya dengan memperhatikan runtutan ayat-ayat Al-Quran sebagaimana tercantum di dalam mushhaf Al-Quran. Model penyajiannnya bersifat deskriptif, analisis dan komparatif, yaitu model penelitian yang berusaha menggali sejauh mungkin produk tafsir yang dilakukan ulama-ulama tafsir terdahulu dari berbagai literartur tafsir, baik yang disusun oleh ulama tafsir yang bersangkutan maupun oleh ulama lain. Data-data yang dihasilkan oleh literatur tersebut kemudian dideskripsikan secara lengkap serta dianalisa dengan menggunakan pendekatan kategoris dan perbandingan.

Tafsir yang ia tulis, ia namai dengan nama: Tafsir Al-Misbah; Pesan, Kesan dan Keserasian Al-Quran. Dengan harapan tafsirnya tersebut bisa menjadi penerang kepada umat bak lentera yang menerangi sekelilingnya, sehingga pada gilirannya dapat memberikan pencerahan yang sejuk bagi mereka-mereka yang haus akan kaijan-kajian Al-Quran dan tafsirnya.

Betapapun Quraish Shihab mumpuni dalam tafsir, ia dengan rendah hati menyampaikan bahwa apa yang dihidangkan dalam Tafsir AlMisbah, bukan sepenuhnya hasil ijtihadnya, di dalamnya banyak dinukil hasil karya ulamaulama terdahulu dan kontemporer. Ulamaulama tersebut antara lain: Ibrâhîm ibn 'Umar al-Biqa'î (w. 885 H/1480 M), Sayyid Muhammad Thanthâwî, Syaikh Mutawallî al-Sya'râwî, Sayyyid Qutub, Muhammad Thâhir ibn Asyur, Sayyid Muhammad Husein Thabathaba'i, serta pakar tafsir lainnya.

\section{METODOLOGI PENELITIAN}

1. Teknik Pengumpulan Data

Penelitian ini bersifat kepustakaan murni (library research), Karena pembahasan ini berkaitan dengan kajian tafsir yang ditulis oleh Prof. Dr. Hamka dan Prof. Dr. Quraish Shihab, maka sumber primer dalam penulisan tesis ini merujuk kepada tafsir yang dikarang oleh kedua tokoh tersebut, yaitu Tafsir Al Azhar dan Tafsir Al-Misbah.

Sedangkan sumber-sumber pendukung lain, penulis mengumpulkan bahan bacaan dari buku-buku sekunder, baik karangan kedua mufassir tersebut, Prof. Hamka dan Prof. M. Quraish Shihab, maupun sumber-sumber lain yang relevan dengan topik pembahasan. Sumber sekunder yang penulis kumpulkan antara lain: Kenang-Kenangan Hidup, Pendidikan Agama Islam, dan Tasawuf Modern karya Prof. Hamka, serta Membumikan Al-Quran, Wawasan AlQur'an, Mukjizat Al-Qur'an, dan Fatwa-Fatwa Seputar Wawasan Agama karya Prof. Dr. H. M. Quraish Shihab.

Untuk mempermudah pencarian ayatayat Al-Qur'an yang membicarakan masalah yang dibahas, penulis menggunakan buku al-Mu'jam al-Mufahras li Alfâdz Al-Qur'an alKarim karangan Fu'âd 'Abd al-Bâqî.

2. Metode Pendekatan dan Analisis

Mengingat pendekatan studi yang akan digunakan dalam penulisan ini adalah pendekatan perbandingan atau komparatif, maka langkah yang paling tepat untuk pendekatan tersebut adalah deskriptif analitik, yaitu memaparkan terlebih dahulu seluruh pemikiran Prof. Dr. Hamka dalam Tafsir AlAzhar dan Prof. Dr. H. M. Quraish Shihab dalam Tafsir Al-Misbah. Kemudian, penulis mengkaji, menganalisa, dan mencari subtansi dari isi kitab-kitab tersebut, terutama yang terkait dengan ayat-ayat yang sedang dikaji. Selanjutnya, penulis mengkonstruksikan kesimpulan-kesimpulan dari analisa tersebut.

Selain deskriftif analitik, penulis mencoba memaparkan data penelitian ini dengan cara analisis kritis, komparasi, dan interpretasi atas berbagai hasil penelusuran dari sumber-sumber primer dan sekunder. Karena data penilitian ini bersifat kualitatif, maka pengolahannya juga dilakukan secara analisis kualitatif. Dengan demikian, substansi penelitian ini adalah kualitatif dengan korelasi jaringan variabelnya yang kualitatif pula.

\section{PEMBAHASAN}

\section{Hakikat Sabar}

Dalam menganalisis pandangan Prof. Dr. Hamka dan Prof. Dr. Quraish Shihab mengenai hakikat sabar ini, penulis menempuh dua cara, yaitu: (1) mengemukakan penafsiran kedua mufassir tersebut, (2) membandingkan pendapat keduanya secara kritis dengan pendekatan deskriptif analitis.

Sebagaimana dipaparkan dalam bab 3 dan 
bab 4, hakikat kesabaran adalah kemampuan seseorang dalam mengendalikan diri, menaati perintah Allah, dan menghadapi ujian dan cobaan dari Allah. Dalam bab ini, penulis mengambil sebagian ayat yang mewakili pandangan Hamka dan Qurasih Shihab tentang hakikat sabar tersebut, yaitu meliputi tiga hal berikut.

\section{Mengendalikan Diri}

"Maka sabarlah engkau (Muhammad) atas apa yang mereka katakan, dan bertasbihlah dengan memuji Tuhanmu, sebelum matahari terbit dan sebelum terbenam dan bertasbih (pula) pada waktu tengah malam dan di ujung siang hari, agar engkau merasa tenang." (QS Thâ Hâ [20]: 130)

Dalam menafsirkan ayat ini, Hamka menceritakan perilaku-perilaku kaum musyrik Mekah yang kerap menyerang Nabi Saw, baik dengan cemoohan dan hinaan, maupun dengan ancaman yang ditujukan kepadanya. Tujuan mereka ialah agar Nabi berhenti melakukan kegiatan dakwah kepada penduduk Mekah. Dalam uraiannya, Hamka menyebut bahwa sebagai seorang manusia, Nabi tersinggung perasaannya. Namun, Nabi diperingatkan melalui ayat ini, supaya dia bisa mengendalikan diri dan bersabar, serta tabah dalam menghadapi segala macam omongan dan cemoohan mereka. Perintah sabar terhadap perlakuan kaum musyrik ketika mencela dakwah Nabi tersebut juga tertuang dalam QS Qâf (50): 39, sedangkan pada QS. Al-Muzammil (73): 10, Nabi diperintahkan meninggalkan mereka dengan cara yang baik.

Kesabaran tersebut, hendaknya dibarengi dengan memuji Tuhan agar tetap dalam lindungan Allah Swt. Hamka menegaskan bahwa orang-orang mu'min yang berjuang menegakkan kebenaran Ilahi, supaya mereka memegang teguh kesabaran dan takwa. Sabar yang berarti tabah, jangan tergoncang oleh sepak terjang, tingkah laku dan tipu daya busuk musuh-musuh Allah swt. Sebab yang demikian akan mengurangi tenaga mereka yang sedang berjuang. Agar kesabaran bisa teguh, hendaknya selalu diberi dasar takwa, karena takwa adalah hubungan pribadi dengan Allah. Pribadi yang bertakwa itulah yang akan sanggup menahan hati memiliki ketabahan dan tetap bersabar sehingga berjalan terus menuju apa yang dimaksud.

Di ayat lain, seperti QS al-Baqarah (2): 153, Hamka mengatakan bahwa sebuah tujuan besar seperti menegakkan tauhid-yakni tauhid yang bebas dari kemusyrikan, dan tauhid yang tidak tercampur khurafat dan takhayul-tentu tidaklah mudah, banyak rintangan, cobaan, dan godaan yang menghadang. Semuanya itu harus dijalani dan dibarengi dengan kesabaran, di samping juga harus disertai dengan shalat sebagai jalan mendekatkan diri kepada Tuhan.

Tampaknya pendekatan yang dilakukan oleh Hamka tersebut didasari oleh pengalamanpengalaman yang ia alami ketika menjalankan dakwahnya di Minangkabau dan Sumatra. Dalam upayanya memberantas praktik-praktik keagamaaan yang menyimpang dan memurnikannya, Hamka kerap dituduh telah sesat dan bahkan dicap kafir. Ini pula yang pernah dialami oleh ayahnya, Abdul Karim Amrullah. Cemoohan dan tuduhan semacam ini menjadi sebuah konsekuensi seorang mubaligh seperti dirinya. Oleh karena itu, bagi seorang mubaligh diperlukan kesabaran yang tinggi.

Dalam pandangan Hamka, nabi-nabi sebelum Nabi Muhammad saw., semuanya mengalami kesulitan dalam menyampaikan risalah dakwah. Kemenangan mereka hanya ada pada kesabaran. Nabi Yaqub a.s. misalnya, ia sabar menunggu pulang anaknya yang hilang lebih dari 25 tahun, bahkan sampai berputih mata, dan akhirnya Yusuf a.s. kembali juga. Tujuh tahun Yusuf a.s. menderita dipenjara karena suatu fitnah, namun dengan kesabarannya, ia jalani nasibnya; akhirnya dia dipanggil untuk menjadi menteri besar. Bertahun-tahun Ayub a.s menderita penyakit sehingga tersisih dari anak istri, akhirnya penyakitnya disembuhkan Allah dan setelah pulang ke rumah didapatinya anak yang 10 telah menjadi 20 oleh karena semuanya sudah kawin dan beranak. Demikian pula Ibrahim a.s dapat menyempurnakan kalimat-kalimat ujian Tuhan karena sabar, Musa a.s. bersama Bani Israilnya, dan Ismail a.s. yang membangun angkatan Arab menuju peradaban baru, dan Isa al-Masih dengan hawariyyin, semuanya dilewatinya dengan sabar.

Lebih lanjut Hamka memberi anjuran agar jangan memperdulikan halangan orang yang menghalangi dan kebencian orang yang benci, melainkan lebih baik sabar, tahan hati dan tabah. Sabar yang indah, maksudnya sikap tenang, 
tidak lekas marah, tidak naik darah, menerima cemoohan itu dengan senyum simpul, jangan termenung dan putus asa, lanjutkan usaha dan jangan berhenti di tengah jalan.

Quraish Shihab juga menafsirkan ayat QS Thâ Hâ (20): 130 di atas serupa dengan yang dikemukakan oleh Hamka. Pendeknya, bahwa Nabi Muhammad diperintahkan oleh Allah swt agar bersabar atas apa yang mereka (orang-orang kafir) katakan, baik yang berupa pendustaan terhadap ajaran yang Nabi sampaikan, maupun cemoohan terhadap dirinya dan pengikutnya, disertai dengan bertasbih menyucikan Tuhan dari segala yang tidak wajar bagi-Nya. Demikian akan membuat hati merasa tenang, senang dan puas terhadap apa yang terjadi.

Pada QS al-Anâm (6): 34 dijelaskan bahwa pendustaan kaum musyrikin Mekah terhadap para rasul bukan hanya terjadi pada diri Nabi Muhammad saw. Rasul-rasul sebelum Muhammad Saw. juga telah didustakan oleh masyarakatnya, tetapi mereka mendapatkan pertolongan Allah swt. karena kesabarannya.

Dalam penjelasan ayat di atas, Quraish Shihab mengatakan bahwa sebagian ulama memahami apa yang dialami oleh para rasul terdahulu lebih berat daripada yag dialami oleh Nabi Muhammad saw. Mereka pahami ini dari pengabungan dua kata, yakni "pendustaan" dan "gangguan", ketika ayat di atas berbicara tentang para rasul. Sedangkan ketika berbicara tentang Nabi Muhammad saw., yang disebut hanya satu kata, yaitu "pendustaan" (baca: QS al-Anâm [6]: 33). Pendapat ini menurut Quraish tidak sepenuhnya benar, karena Rasulullah saw. pun mengalami ganguan dari umatnya. Bahkan, secara tegas QS Âli 'Imrân (3): 186 menyatakan: "Kamu sungguh akan mendengar dari orangorang yang diberi al-Kitab sebelum kamu dan orang-orang yang mempersekutukan Allah, gangguan yang banyak."

Lebih lanjut, Quraish Shihab berpendapat: "boleh jadi disebutnya kata gangguan pada ayat 34 dan tidak disebutnya pada ayat 33 itu untuk lebih mendorong Nabi Muhammad Saw meneladani para rasul itu dalam kesabaran dan ketabahan mereka.

\section{Menaati Perintah Allah}

Dan taatilah Allah dan Rasul-Nya dan janganlah kamu berselisih, yang menyebabkan kamu menjadi gentar dan kekuatanmu hilang dan bersabarlah. Sungguh, Allah beserta orangorang sabar. (QS Al-Anfâl [8]: 46)

Dalam kaitan dengan hakikat sabar berupa ketaatan menjalankan perintah Allah, Hamka menekankan diperlukannya perilaku sabar dalam melaksanakan kewajiban-kewajiban yang dibebankan kepadanya berupa shalat, zakat, puasa dan haji, demikian juga sabar dan tahan hati ketika dalam peperangan dengan tidak berselisih pendapat, akan tetapi tetaplah selalu mengkuti apa yang diperintahkan oleh pemimpinnya. Hal ini karena kalau berselisih justru akan mengurangi kekuatan pasukan muslimin dalam memperoleh kemenangan.

Keterangan di atas mengisyaratkan bahwa dalam ketaatan pun seorang mukmin dituntut bersabar. Selanjutya kesabaran menaati perintah Allah ini mencakup dua hal, yaitu: (1) ketika dalam keadaan damai, dan (2) dalam keadaan perang. Dalam keadaan damai, seperti melaksanakan kewajiban-kewajiban agama (syaríah), seorang dituntut bersabar di dalamnya, sehingga yang muncul dari ketaatan tersebut adalah sikap ikhlas dan tawakal terhadap keputusan ataupun ketentuan Allah swt, bukan menjadikan ketaatan tersebut sebagai beban dan pengharapan akan turunnya nikmat dari Allah.

Sementara itu, Quraish Shihab memandang bahwa ayat di atas dan ayat-ayat berikutnya adalah konsekuensi dari kesimpulan ayat-ayat sebelumnya yang diakhiri dengan pernyataan bahwa: "hanya kepada Allah dikembalikan segala urusan." Sehingga ayat ini seakan-akan menyatakan jika demikian itu halnya, maka hai orang-orang yang beriman, apabila kamu menemui, yakni memerangi pasukan musuh yang wajar diperangi, dimana dan kapanpun, maka berteguh-hatilah dalam menghadapi mereka, yakni jangan sampai semangat dan usaha kamu mempertahankan kebenaran menjadi lemah atau berkurang, dan sebutlah nama Allah sebanyak-banyaknya, ingat juga janji dan kekuasaan-Nya serta berdoalah kiranya kamu dianugerahi kemenangan agar kamu beruntung memperoleh segala apa yang kamu harapkan. Dan taatilah Allah yang mahakuasa dan rasul-Nya yang memimpin kamu dalam keadaan damai dan perang, dan janganlah kamu berselisih, berbantah-bantahan, yang menyebabkan kamu menjadi gentar, lemah dan mengendor semangat kamu, bahkan gagal, 
lumpuh dan hilang kekuatan kamu. Bersabarlah dalam menghadapi segala situasi dan tantangan. Sesungguhnya Allah beserta orang-orang yang sabar, yakni selalu mengetahui keadaan mereka dan membantu mereka.

Berdasarkan uraian di atas, dapat dipahami bahwa, Hamka lebih rinci menjelaskan sabar kaitannya dalam menaati perintah Allah. Adapun Quraish Shihab, beliau tidak menjelaskan tentang sabar menaati perintah Allah dalam keadaan damai. Beliau hanya memaparkan tentang sabar menaati perintah Allah dalam keadaan perang, yaitu dengan cara memperbanyak berdzikir, berdo'a, tidak berselisih, tidak berbantah-bantahan, taat kepada pemimpin dan bertawakkal kepada Allah swt.

\section{Buah Sabar di Dunia dan Akhirat}

1. Buah Sabar di dunia

a. Mendapatkan yang Diinginkan

"Dan telah sempurnalah firman Tuhanmu yang baik itu (sebagai janji) untuk Bani Israil disebabkan kesabaran mereka. (QS. al-A'râf [7] : 137).

Dalam memberikan penafsiran tentang ayat ini, Hamka terlebih dahulu menguraikan secara panjang lebar sejarah Fir'aun sebagai suatu kerajaan besar yang berkuasa penuh dan memiliki berbagai rencana pembangunan yang begitu besar. Namun, pada akhirnya semua kerajaannya hancur lebur dan terlantar sehingga tidak dapat diteruskan lagi. Hal ini dikarenakan sang raja (Fir'aun) tenggelam bersama orang-orang besarnya. Kekuasaan yang pada awalnya diduga tidak ada yang dapat menumbangkannya ternyata hancur oleh sebab kesabaran Bani Isra'il yang juga berkat kepemimpinan yang teguh Nabi Musa a.s. Kisah tenggelamnya Fir'aun termaktub dalam Al-Qur'an supaya meninggalkan kesan di dalam hati orang-orang yang beriman, bahwa penjajahan dan penindasan adalah siksa dunia yang paling pahit bagi suatu bangsa. Oleh karena itu, bangsa yang tertindas wajib membangkitkan semangatnya, meskipun mereka hampir mati atau tengah putus asa yang berurat akar. Ketika Nabi Musa a.s. memimpin Bani Israil, dia menanamkan dalam sanubari mereka bahwa bagaimanapun kuatnya Fir'aun, hati mereka seluruhnya tertumpu pada kekuasaan yang lebih tinggi daripada kekuasaan dunia, yaitu kekuasaan Allah swt.

Sementara Quraish Shihab dalam menafsirkan ayat tersebut mengatakan bahwa kerajaan-kerajaan yang telah dibangun oleh Fir'aun dan bala tentaranya berupa gedung-gedung tinggi dan istana-istana yang megah serta rezim yang dibangunnya yang menguasai dan menindas negeri-negeri bagian timur bumi, yakni Syam, juga negeri-negeri barat, dihancurkan oleh Allah swt. Ketika Fir'aun dan bala tentaranya tenggelam di laut, semua peninggalan-peninggalan Fir'aun diwariskan kepada Bani Israil karena mereka sabar dan taat terhadap janji Allah yang akan menjadikan Bani Israil penguasa-penguasa di bumi.

\section{b. Menjadi Pemimpin Kaum}

Dan Kami jadikan di antara mereka itu pemimpin-pemimpin yang memberi petunjuk dengan perintah Kami selama mereka sabar. Mereka meyakini ayat-aayat ayat Kami. (QS AlSajdah [32]: 24)

Dalam menafsirkan ayat ini, Hamka mengatakan bahwa untuk mencapai derajat yang tinggi, menjadi imam-imam suatu kaum, haruslah disertai dengan sabar. Nabi Musa dan Nabi Harun, seperti diceritakan dalam sebuah ayat "tatkala mereka bersabar" mencapai derajat yang tinggi, mereka menjadi imam bagi kaumnya, yaitu karena mereka bersabar. Ini menjadi pedoman bahwa barang siapa yang ingin menjadi pemimpin suatu kaum, maka harus bersabar. Sebab, untuk naik ke derajat pimpinan tidaklah mudah, tetapi harus melalui berbagai macam rintangan dan halangan.

Sementara Quraish Shihab menafsirkan QS Al-Sajdah (2): 24 tersebut dengan menegaskan bahwa kesabaran dan ketaatan Bani Israil kepada Allahlah yang di kemudian hari membuahkan hasil, bukan saja apa yang ditinggalkan Fir'aun, melainkan juga lahirnya pemimpin-pemimpin yang baik dan adil, serta dapat memberikan suri tauladan yang baik, meskipun sebagian kalangan Bani Israil sendiri ada pula yang menolaknya. Para pemimpin itu memberikan petunjuk kepada masyarakatnya serta mengantar mereka menuju kebahagiaan dan kesejahteraan hidup dengan berdasarkan pada perintah Allah. Demikianlah Allah menjadikan mereka pemimpin disebabkan oleh kesabaran dan ketabahan menghadapi tantangan dan melaksanakan tugas-tugasnya. 
c. Memperoleh Pertolongan Allah

"Ya (cukup), jika kamu bersabar dan bertakwa ketika mereka datang menyerang kamu dengan tiba-tiba, niscaya Allah menolongmu dengan lima ribu malaikat yang memakai tanda." (QS. Âli 'Imrân [3]: 125)

Dalam menafsirkan ayat di atas, Hamka menjelaskan bahwa modal utama dalam memperoleh pertolongan Allah, yakni kemenangan yang dapat mudah tercapai adalah dengan sabar. Seperti dijelaskan pada ayat sebelumnya, Tuhan telah berpesan kepada kaum muslimin agar bersabar dalam menghadapi sikap benci dan dendam kaum musyrik. Jika kaum muslimin mampu bersabar dan bertakwa niscaya tipu daya kaum musyrik tidak akan mencelakakan mereka.

Pada ayat ini pula, Hamka menjelaskan bahwa Rasulullah pada saat Perang Uhud telah menyampaikan kepada pasukan kaum muslimin bahwa meskipun mereka hanya 700 orang dan musuh lebih dari 3000 orang, Tuhan akan mendatangkan 3000 malaikat sebagai pembantu. Dan apabila ditambah dengan sabar dan takwa mereka bahkan akan datang 5000 malaikat menyerbu musuh bersama mereka.

Selanjutnya, Hamka menilai bahwa kunci keberhasilan perjuangan adalah sabar. Hanya orang yang sabar dan beramal shalih yang selamat dari ombang-ambing hidup. Sabar, tahan hati, jiwa besar, tidak sombong ketika ada, tidak mengeluh ketika hilang. Sabar dan terus beramal terus bekerja yang baik. Bukan sabar tapi termenung, dan ini hanya ada pada orang yang memupuk iman dalam dadanya. Orang inilah yang akan tahan menderita dan bahwa ketika ditimpa sukacita "mereka itu bagi mereka adalah ampunan dan ganjaran yang besar".

Sementara itu, Quraish Shihab menafsirkan QS Âli 'Imrân (3): 125 dengan menjelaskan bahwa Allah berpesan kepada kaum muslimin agar bersabar, tabah dan bertakwa. Sebab, jika mereka bersabar dalam mendisiplinkan diri, tidak terbawa oleh hawa nafsu dan cinta yang bukan pada tempatnya. Dan bertakwa, yakni menghindari tipu daya mereka (musuh Allah) atau bertakwa kapada Allah dengan melaksanakan seluruh tuntunannya termasuk menangkal tipu daya mereka, niscaya tipu daya mereka sedikitpun tidak akan mendatangan kemudharatan kepadanya. Tetapi bila tidak bertakwa, maka bahaya dapat menimpanya.

2. Buah Sabar di Akhirat

a. Mendapatkan Derajat Tinggi di Surga

Mereka itu akan diberi balasan dengan tempat yang tinggi (dalam surga) atas kesabaran mereka dan di sana mereka akan disambut dengan penghormatan dan salam (QS. AlFurqân [25]: 75)

Dalam menafsirkan ayat ini, Hamka menjelaskan bahwa orang-orang yang sabar akan diberi tempat yang mulia, bilik atau kamar yang indah permai, ruangan yang istimewa dalam surga. Karena orang-orang yang berjalan menegakkan kebenaran, akan menjadi hamba yang taat dan patuh serta sabar. Oleh karena itu mereka pantas mendapatkan kebahagiaan jiwa, menempati surga jannatunna'im, dan tempat tinggal yang tentram.

Setiap mukmin pasti mengharapkan dirinya masuk ke dalam surga Allah. Namun, masuk ke dalam surga tidaklah semudah itu. Allah meminta kesungguh-sungguhan, semangat, antusias dan kesabaran sebagai ujian dalam mendapatkan surga-Nya. Sebab, surga meminta pengorbanan, jihad, kesungguhan, dan kerja keras. Itulah syarat pertama perjuangan. Syarat keduanya ialah sabar, tahan menderita dan tabah. Dengan demikian, seorang pejuang tidaklah akan masuk surga sebelum Allah membuktikan, memperlihatkan dengan jelas siapa pejuang yang sunguh-sungguh dan siapa yang sabar, siapa yang tahan dan siapa yang tabah.

Sementara Quraish Shihab menafsirkan ayat ini dengan menyebut secara singkat ganjaran mereka yang sabar. Ia mengatakan bahwa orang-orang sabar akan dibalas atas dasar anugerah-Nya dengan martabat yang tinggi di dalam surga. Hal itu karena kesabaran dan ketabahan mereka melaksanakan tuntunan agama. Di samping itu, mereka juga disambut di sana, yakni di tempat yang tinggi di surga, oleh para malaikat dengan penghormatan dan ucapan salam. Mereka hidup bahagia kekal di dalamnya dalam keadaan puas sehingga tidak lagi menginginkan sesuatu selain yang telah disediakan buat mereka di sana. Alangkah baik tempat menetap dan tempat kediaman itu.

Ayat tersebut juga menjelaskan beberapa prinsip umum yang berkaitan perjuangan meraih surga, sekaligus menjelaskan bahwa malapetaka dan cobaan yang dialami kaum 
muslimin itu adalah untuk mengantar mereka masuk surga.

b. Mendapatkan Pahala Tanpa Batas.

"Hanya orang-orang yang bersabarlah yang disempurnakan pahalanya tanpa batas". (QS. al-Zumar [39]: 10)

Dalam menafsirkan ayat ini, Hamka menjelaskan bahwa alat untuk memperoleh petunjuk Ilahi, yang akan membawanya bahagia di dunia dan akhirat ialah dengan sabar, tabah hati. Sebab, hanya orang-orang yang bersabar yang akan sampai pada apa yang menjadi tujuannya, yaitu mendapatkan pahala yang berlipat ganda di sisi Allah.

Hamka mengutip pendapat Ibn Jarir yang mengatakan bahwa sejatinya yang akan mencapai ilmu hakikat adalah orang-orang yang sabar; sabar dalam menghadapi rayuan dunia, dan sabar di dalam membina amal untuk bekal menuju ke akhirat.

Menurut Imam al-Auzấî, orang-orang yang sabar dan tahan menderita di akhirat kelak tidaklah ditimbang berat atau ringan amalnya melainkan sudah disediakan buat mereka bilik-bilik istirahat yang mulia di sisi surga. Hal ini berdasarkan hadits yang diriwayatkan oleh Anas bin Malik, bahwa Rasulullah saw. bersabda, "Semua amal akan ditimbang kelak dengan teliti, namun ahlul-balâ (orang yang tabah menghadapi ujian) tidak ditimbangtimbang lagi...

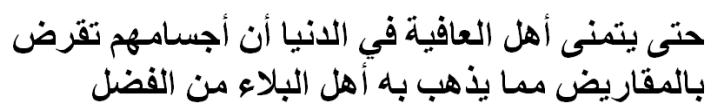

"Sehingga berkeinginanlah orang-orang yang sehat-sehat saja di dunia kalau kiranya dahulu badannya digergaji dipotong-potong, setelah mereka lihat bagaimana kelebihan dan keistimewaan yang akan diterima oleh orangorang yang sabar menderita."

Itulah maksud pahala yang akan diberikan dengan tidak ada perhitungan lagi.

Sementara itu, Quraish Shihab dalam menafsirkan ayat ini mengatakan bahwa berhijrah meninggalkan tumpah darah dan sanak saudara adalah sesuatu yang berat dan memerlukan tekad serta kesabaran, tetapi ketahuilah bahwa sesungguhnya hanya orang-orang yang sabar, yakni yang mantap tekad dan kesabarannya, hanya mereka itulah yang disempurnakan pahala mereka tanpa perhitungan, yakni dianugerahi pahala yang sangat banyak sehingga tidak dapat terhitung bahkan tidak terbatas. Sebab, sesuatu yang tidak dapat terhitung berarti tidak terbatas.

\begin{tabular}{|c|c|c|c|c|}
\hline \multicolumn{5}{|c|}{ Tabel Komparasi Penafsiran HAMKA dan Quraish Shihab } \\
\hline No. & Topik & Ayat & Penafsiran HAMKA & Penafsiran M. Quraish Shihab \\
\hline 1 & $\begin{array}{l}\text { Sabar sebagai Pengendalian } \\
\text { Diri }\end{array}$ & QS Thaha (20): 130 & $\begin{array}{l}\text { - Mengendalikan diri, tabah menghadapi } \\
\text { cemoohan } \\
\text { - Dibarengi dengan memuji Tuhan } \\
\text { - Memegang teguh takwa } \\
\text { - Diiringi dengan shalat }\end{array}$ & $\begin{array}{l}\text { - Bersabar atas pendustaan dan cemoohan orang } \\
\text { kafir } \\
\text { - Disertai dengan penyucian Tuhan } \\
\text { - Bersabar agar hati merasa tenang dan senang }\end{array}$ \\
\hline 2 & $\begin{array}{l}\text { Sabar dalam menaati } \\
\text { perintah Allah }\end{array}$ & QS Al-Anfaal (8): 46 & $\begin{array}{l}\text { - Sabar dalam perang = kewajiban shalat, } \\
\text { puasa, zakat, dan haji } \\
\text { - Sabar dengan tidak berselisih pendapat } \\
\text { - Selalu taat mengikuti perintah-Nya } \\
\text { dalam keadaan damai dan perang }\end{array}$ & $\begin{array}{l}\text { - Teguh hati dalam perang } \\
\text { - Menjaga semangat agar tidak lemah } \\
\text { - Menaati Allah dan Rasul-Nya dalam keadaan } \\
\text { perang }\end{array}$ \\
\hline 3 & $\begin{array}{l}\text { Sabar dalam menghadapi } \\
\text { ujian }\end{array}$ & QS Al-Baqarah (2): 155 & $\begin{array}{l}\text { - Sabar dalam menghadapi ketakutan } \\
\text { ancaman musuh Allah } \\
\text { - Sabar dalam kelaparan, kekurangan } \\
\text { harta, dan kehilangan sanak saudara } \\
\text { - Sabar mengatasi semua masalah }\end{array}$ & $\begin{array}{l}\text { - Hakikat kehidupan adalah ujian } \\
\text { - Orang yang lulus ujian ialah yang sabar } \\
\text { - Sabar dalam } 4 \text { hal: } \\
\text { 1. Menghadapi ejekan dan rayuan } \\
\text { 2. Melaksanakan perintah Allah } \\
\text { 3. Menghadapi petaka dan kesulitan } \\
\text { 4. Berjuang menegakkan kebenaran dan } \\
\text { keadilan }\end{array}$ \\
\hline 4 & $\begin{array}{l}\text { Buah sabar di dunia: Karunia } \\
\text { yang besar }\end{array}$ & QS Al-A raf (7): 137 & - Bani Isra il meraih kemenangan yang & - Bani Isra `il mewarisi peninggalan Fir ’aun \\
\hline 5 & $\begin{array}{l}\text { Buah sabar di dunia: Menjadi } \\
\text { Pemimpin }\end{array}$ & QS AI-Sajdah (32): 24 & $\begin{array}{l}\text { - Dengan sabar Bani Isra `il di jadikan } \\
\text { pemimpin }\end{array}$ & - Karena sabar, Bani Isra ill menjadi pemimpin \\
\hline
\end{tabular}




\begin{tabular}{|c|c|c|c|c|}
\hline 6 & $\begin{array}{l}\text { Buah sabar di dunia: } \\
\text { Memperoleh pertolongan } \\
\text { Allah }\end{array}$ & QS Ali Imran (3): 125 & $\begin{array}{l}\text { - Sabar adalah modal utama } \\
\text { memperoleh pertolongan Allah dan } \\
\text { kunci keberhasilan perjuangan } \\
\text { - Hanya orang sabar dan beramal shalih } \\
\text { yang selamat dari ombang-ambing } \\
\text { hidup } \\
\text { - Orang sabar memupuk iman, tahan } \\
\text { derita, memperoleh ampunan, dan } \\
\text { ganjaran besar } \\
\text { - Sabar ialah tahan hati, teguh semangat } \\
\text { dan tabah } \\
\text { - Jika bersabar dan takwa dibantu } 5000 \\
\text { malaikat }\end{array}$ & $\begin{array}{l}\text { - Allah berpesan agar kaum muslim bersabar, } \\
\text { tabah dan bertakwa } \\
\text { - Sabar harus dengan disiplin } \\
\text { - Sabar tidak terbawa oleh hawa nafsu dan cinta } \\
\text { yang bukan pada tempatnya } \\
\text { - Jika bersabar dan bertakwa Allah } \\
\text { mendatangkan } 5000 \text { malaikat sebagai penolong }\end{array}$ \\
\hline 7 & $\begin{array}{l}\text { Buah sabar di akhirat: Derajat } \\
\text { tinggi di Surga }\end{array}$ & QS Al-Furqan (25): 75 & $\begin{array}{l}\text { - Sabar yang dibalas dengan surga ialah } \\
\text { sabar yang sungguh-sungguh, antusias, } \\
\text { tahan ujian, jihad, dan kerja keras }\end{array}$ & $\begin{array}{l}\text { - Sabar yang dibalas dengan surga yang tinggi } \\
\text { ialah kesabaran dan ketabahan melaksanakan } \\
\text { tuntutan agama }\end{array}$ \\
\hline 8 & $\begin{array}{l}\text { Buah sabar di akhirat: Pahala } \\
\text { tanpa batas }\end{array}$ & QS Al-Zumar (39): 10 & $\begin{array}{l}\text { - Sabar yang tabah hati dalam } \\
\text { menghadapi rayuan dunia dan } \\
\text { membina amal menuju akhirat }\end{array}$ & $\begin{array}{l}\text { - Sabar dalam berhijrah meninggalkan tanah } \\
\text { tumpah darah dengan tekad yang kuat }\end{array}$ \\
\hline 9 & $\begin{array}{l}\text { Akibat tidak sabar dalam } \\
\text { menerima makanan }\end{array}$ & QS AI-Baqarah (2): 61 & $\begin{array}{l}\text { - Bani Isra 'il ditimpa kenistaan, } \\
\text { kemiskinan, dan kemurkaan dari Allah } \\
\text { karena tidak sabar atas makanan } \\
\text { manna dan salwa }\end{array}$ & $\begin{array}{l}\text { - Bani Isra 'il ditimpa kenistaan, kemiskinan, dan } \\
\text { kemurkaan dari Allah karena mencerca makanan } \\
\text { manna dan salwa serta bersikap tidak sopan } \\
\text { kepada Nabi Musa }\end{array}$ \\
\hline 10 & $\begin{array}{l}\text { Akibat tidak sabar dalam } \\
\text { berdakwah }\end{array}$ & QS AI-Qalam (68): 48 & $\begin{array}{l}\text { - Nabi Yunus kurang sabar dalam } \\
\text { berdakwah, sehingga ditakdirkan } \\
\text { masuk ke perut ikan dalam beberapa } \\
\text { hari }\end{array}$ & $\begin{array}{l}\text { - Contoh akibat ketidak sabaran Nabi Yunus } \\
\text { dalam berdakwah yang ditampilkan dengan } \\
\text { pertaubatan dan ketulusan beliau dalam } \\
\text { berdo'a }\end{array}$ \\
\hline
\end{tabular}

\section{KESIMPULAN DAN SARAN Kesimpulan}

Setelah memaparkan tentang hakikat sabar dalam perpektif Al-Quran yang ditinjau dari penafsiran Prof. Dr. Hamka dan Prof. Dr. M. Quraish Shihab, penulis menyimpulkan beberapa temuan tesis ini sebagai berikut:

1. Al-Quran menginformasikan kepada kita bahwa sabar merupakan sikap yang harus dimiliki oleh setiap mukmin dalam berbagai situasi dan kondisi. Sabar merupakan sikap utama yang menempati kedudukan cukup tinggi di dalam ajaran islam. Hal ini terlihat dari banyaknya penyebutan kata sabar dalam al-Quran. Menurut HAMKA, kata sabar terulang dalam al-Qur'an sampai 101 kali. Sedangkan, menurut M. Quraish Shihab, kata sabar terulang sebanyak 97 kali.

2. Hakikat sabar dalam al-Quran adalah kemampuan bertahan mengendalikan diri baik ketika berada dalam damai ataupun perang, kemampuan bertahan dalam menaati perintah Allah swt., baik dalam keadaan damai maupun perang, dan kemampuan bertahan dalam menghadapi ujian dan cobaan dari Allah swt. Hal ini dapat dipahami dari ayat-ayat yang membahas tentang sabar, yaitu: QS. al-Baqarah (2): 153, QS. al-Anfal (8): 46, dan Q.S.
Thaha (20): 130.

3. Sabar menurut HAMKA adalah suatu sikap dari jiwa yang besar dan terlatih, yang akan diperoleh dengan jalan mengendalikan diri, tabah dalam menghadapi segala ujian, dengan disertai bersyukur kepada Allah dan memegang teguh ketakwaan. Sedangkan menurut M. Quraish Shihab, sabar adalah keberhasilan menahan gejolak hati demi mencapai sesuatu yang baik dengan jalan mensucikan Tuhan.

4. Dalam menafsirkan ayat-ayat sabar, HAMKA lebih banyak memaparkannya dengan mengangkat cerita atau sejarah umat-umat terdahulu, para nabi dan rasul, para sahabat, maupun cerita dari pengalaman hidup pribadi yang beliau alami sendiri selama berdakwah. Hal ini menjadikan penafsiran HAMKA dalam membahas ayat-ayat sabar relatif lebih panjang jika dibanding dengan penafsiran $\mathrm{M}$. Quraish Shihab.

5. Sebagaimana menjadi ciri dalam penafsirannya, M. Qurish Shihab dalam menafsirkan ayat-ayat sabar mencoba menguraikan dan mambahas kata sabar dalam berbagai bentuk dan cakupannya, kemudian beliau merangkaikan kata-kata (sebagai tambahan kata untuk memperjelas maksud ayat) yang disisipkan ke dalam ter- 
jemahan ayat sehingga terangkai kata-kata yang mudah dipahami tentang maksud sebuah ayat. Tidak jarang pula beliau mengeksplorasi daya nalar dalam paparan tafsirnya untuk dapat memahami sebuah maksud ayat, sebagaimana dapat kita lihat dalam menafsirkan QS. al-Baqarah (2): 155.

6. Secara umum dalam pembahasan ayat-ayat sabar baik HAMKA maupun M. Quraish Shihab memiliki banyak persamaan, akan tetapi setelah diteliti lebih dalam terdapat perbedaan dalam pemahaman tafsiran ayat, hal ini dapat kita lihat penafsiran keduanya dalam menafsirkan QS. al-Anfal (8): 46. HAMKA dalam menafsirkan ayat tersebut menyimpulkan bahwa sabar dalam menaati perintah Allah Swt. mencakup dua hal, yaitu ketika dalam keadaan damai dan ketika dalam keadaan perang. Akan tetapi, M. Quraish Shihab dalam menafsirkan ayat tersebut sama sekali tidak menyinggung tentang sabar dalam menaati perintah Allah Swt. ketika dalam keadaan damai, melainkan hanya memaparkan tentang sabar dalam keadaan perang.

7. Baik Hamka maupun Quraish Shihab, beliau berdua memaparkan tentang buah dari sabar. Orang-orang yang sabar akan membuahkan hasil yang buahnya dapat dipetik di dunia dan di akhirat, serta memperoleh keutamaanya. Lebih lanjut HAMKA menyebutkan bahwa dalam alQuran terdapat 93 kalimat yang menyinggung tentang keutamaan sabar.

8. Hamka dan Quraish Shihab juga menerangkan tentang akibat dari tidak sabar. Orang-orang yang tidak sabar akan mendapatkan kenistaan, kemiskinan, bahkan murka Allah swt.

\section{Saran}

Untuk menyempurnakan hasil penelitian dalam tesis ini, penulis menyarankan beberapa hal berikut:

1. Kepada masyarakat muslim Indonesia agar mengetahui hakikat sabar dalam perspektif Al-Quran. Dalam perspektif Al-Quran, hakikat sabar adalah kemampuan dalam mengelola emosi atau gejolak hati, baik dalam keadaan positif maupun negatif, pada waktu suka atau duka. Sabar yang demikian menghendaki adanya aktivitas dalam berusaha dan tidak pasif dalam menerima ujian.

2. Kepada para ulama, $d a^{\prime} i$, dan muballigh di Indonesia, hendaknya menerangkan nilainilai akhlak utama di dalam Al-Quran secara komprehensif, sehingga masyarakat muslim lebih berdayaguna, khususnya dalam memahami dan mengaktualisasikan nilai-nilai kesabaran. Hal ini sangat penting mengingat tidak sedikit dari kalangan muballigh yang mengidentikkan kata sabar dengan keadaan pasrah dalam menghadapi cobaan yang diberikan oleh Allah Swt. atau bahkan lebih dari itu, sabar diartikan dengan sikap diam dalam menghadapi ketidakadilan dari para penguasa yang dzalim.

3. Kepada para mahasiswa dan kaum intelektual, hendaklah memperbanyak kajian tentang akhlak-akhlak utama dalam Islam, seperti tentang kesabaran, keuletan, ketabahan, keteguhan hati, dan kemantapan jiwa. Dengan kajian-kajian tersebut diharapkan elemen bangsa yang terdidik semakin berkualitas, sehingga mampu membangun bangsa ini menuju bangsa yang maju dengan disertai ridho Allah swt.

\section{DAFTAR PUSTAKA}

Al-Quran dan Terjemahannya, Depag: 1994

al-Asqalani, Ibnu Hajar, 2006. Nashaih al-Ibad, Jakarta: Pustaka Amani.

Amin, Mohammad, 1997. Sepuluh Induk Akhlaq Terpuji, Kiat Membina dan Mengembangkan SDM, Jakarta: Kalam Mulia.

Amru Muhammad Khalid, 2003. Sabar dan Bahagia, 3 Metode Nabi Mencerdaskan Emosi, Jakarta: Serambi Ilmu Semesta.

Armstrong, Amatullah, 2001. Kunci Memasuki Dunia Tasawuf, Bandung: Mizan.

Al-Haddad, Sayyid Abdullah bin Alawi, 2001. Thariqah Menuju Kebahagiaan, penerjemah Muhammad al-Baqir, Bandung: Mizan.

Al-Qahthani, Said bin Musfir, 2003. Buku Putih Syaikh 'Abdul Qâdir al-Jailani, penerjemah Munirul Abidin, Jakarta: Darul-Falah.

Badawî, Ahmad Ahmad, 1950. Min Balâghah al-Qur'ân, Kairo: Dâr Nahdhah Mishr.

Bahresy, Husein, 1997. Ajaran-Ajaran Akhlaq Imam Ghazali, Surabaya: Al-Ikhlas.

Deliar Noer, 1996. Gerakan Modern Islam 
di Indonesia 1900-1942, Jakarta: LP3SS Indonesia.

Fad'aq, Asma, Umar Hasan, 2000. Mengungkap Makna dan Hikmah Sabar, terj. Nasib Mustafa, Jakarta: Lentera.

al-Ghazâlî, Abû Hâmid, 1989. Ihyâ' 'Ulûm alDîn, Beirut: Dâr al-Fikr, t.t.

-----, Minhâj Al-Ấbidîn, Beirut: Dâr al-Fikr.

------, 2004. Mukâsyafah Al-Qulûb, Kairo: Dâr al-Fajr li al-Turats.

al-Ghazali, Muhammad, 1003. Akhlaq Seorang Muslim, terj. Moh. Rifa'I, Semarang: Wicaksana.

HAMKA (Haji Abdul Malik bin Abdul Karim Amrullah), 1984. Tafsir Al-Azhar, Jakarta: Pustaka Panjimas,

------, 1985. Islam dan Adat Minangkabau, Jakarta: Pustaka Panjimas,

------, 1979. Kenang-Kenangan Hidup, Jakarta: Bulan Bintang,

Islah Gusmian, 2003. Khazanah Tafsir Indonesia, dari Hermeneutika Hingga Ideologi, Jakarta: Teraju.

al-Jauziyah, Ibn Qayyim, 2000. Indahnya Sabar; Bekal Sabar Agar Tidak Pernah Habis, terj. A. M. Halim, Jakarta: Maghfirah Pustaka,

-----, 1999. Sabar Perisai Seorang Mukmin, terj. Fadli, Lc, Jakarta: Pustaka Azizah, , cet. Ke-1

al-Khudhari, Muhammad bin Abdul Aziz, 2001. Sabar, Jakarta: Darul haq.

Majma' al-Lughah al-Aarabiyyah, t.t. Al-Mu'jam al-Wasith, Intanbul: al-Maktabah alIslamiyyah.

al-Maqdisî, Ibn Qudâmah, Mukhtashar Minhâj al-Qâshidîn, Beirut: Dâr al-Fikr,

Masykur, Kahar, 1987. Membina Moral dan Akhlaq, Jakarta: Kalam Mulia.

Munawwir, Ahmad Warson, 1997. Kamus AlMunawwir Arab-Indonesia Terlengkap, Surabaya, Pustaka Progressif.

Murni Jamal, DR. Abdul Karim Amrullah, 2002. Pengaruhnya dalam Gerakan Pembaruan Islam di Minangkabau pada Awal Abad ke20, Leiden-Jakarta: INIS.

al-Qaradhâwî, Yusuf, 1989. Al-Quran menyuruh Kita Sabar, terj. Aziz Salim Basyarahil, Jakarta: Gema Insani Press.

------, 1996. Sabar dan Tawakkal, terj. Kathur Suhardi, Jakarta: Pustaka al-Kausar. 